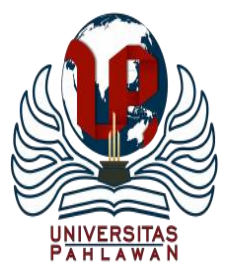

Edukatif : Jurnal Ilmu Pendidikan Volume 3 Nomor 4 Tahun 2021 Halm 1210 - 1219 EDUKATIF: JURNAL ILMU PENDIDIKAN

Research \& Learning in Education

https:/ledukatif.org/index.php/edukatif/index

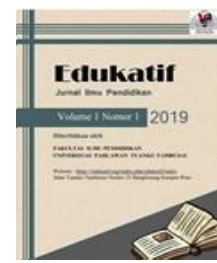

\title{
Pengembangan Bahan Ajar Matematika Berbasis Smart School pada Kegiatan Praktek Kerja Lapangan di SMK
}

\author{
Nurjannah $^{1 凶}$, Sugeng Widodo², Helmy Fitriawan ${ }^{3}$ \\ Program Studi Magister Teknologi Pendidikan,Universitas Lampung, Indonesia ${ }^{1}$ \\ Program Studi Pendidikan Geografi,Universitas Lampung, Indonesia ${ }^{2}$ \\ Program Studi Teknik Elektro,Universitas Lampung, Indonesia ${ }^{3}$ \\ E-mail : Nurjannah3086@gmail.com ${ }^{1}$, sugeng.widodo@fkip.unila.ac.id ${ }^{2}$, helmy.fitriawan@eng.unila.ac.id ${ }^{3}$
}

\begin{abstract}
Abstrak
Penelitian ini bertujuan untuk menghasilkan bahan ajar matematika berbasis smart school untuk meningkatkan efektivitas pembelajaran pada kegiatan siswa Praktek Kerja Lapangan (PKL). Penelitian ini merupakan penelitian pengembangan, dengan desain penelitian yang digunakan adalah Reserch and Development (R\&D) dengan model ADDIE (Analyze, Desaign, Development, Implementation, Evaluation) yang terdiri dari lima tahap yaitu tahap analisis, tahap perancangan, tahap pengembangan, tahap implementasi dan tahap evaluasi. Kevalidan produk dilihat dari hasil validasi ahli dengan mencapai kriteria valid untuk bahan ajar. Keefektifan produk dilihat dari hasil posttest yang dilakukan pada saat uji coba lapangan dengan hasil lebih dari 75\% siswa mencapai Kriteria Ketuntasan Minumum (KKM). Hasil Penelitian berdasarkan penilaian ahli materi penilaian persentase rata-rata 92,65\% kategori sangat layak, penilaian ahli media persentase rata-rata 96,43\% kategori sangat layak dan persentase rata-rata penilaian ahli desain 89,28\% dengan kriteria sangat layak, penilaian peserta didik pada uji terbatas 26 siswa persentase rata-rata 76,61\% dan penilaian lima orang teman sejawat persentase rata-rata 92,78\%. Berdasarkan penilaian ahli materi, ahli media, ahli desain, respon peserta didik dan teman sejawat maka dapat disimpulkan bahwa bahan ajar matematika materi statistika berbasis smart school layak digunakan untuk meningkatkan efektivitas pembelajaran pada saat kegiatan siswa Praktek Kerja Lapangan.
\end{abstract}

Kata Kunci: Bahan ajar, smart school, Praktek Kerja Lapangan.

\begin{abstract}
This study aims to produce smart school-based mathematics teaching materials to improve the effectiveness of learning in field work practice student activities. This research is a development research, with the research design used is Reserch and Development $(R \& D)$ with ADDIE (Analyze, Desaign, Development, Implementation, Evaluation). The validity of the product is seen from the results of expert validation by achieving valid criteria for teaching materials. The effectiveness of the product is seen from the posttest results presented during the field trials with the results of more than 75\% of students achieving the Minumum Completion Criteria. The results of the study based on expert assessment material assessment of an average percentage of $92.65 \%$ category is very feasible, media expert assessment average percentage $96.43 \%$ category is very feasible and persantese average design expert assessment $89.28 \%$ with very decent criteria, assessment of learners in the limited trial 26 students average percentage $76.61 \%$ and assessment of five peers percentage average $92.78 \%$. Based on the results of the assessment, it can be concluded that the math teaching materials based on smart school statistics are worth using to improve the effectiveness of learning during the activities of field work practice students.
\end{abstract}

Keywords: Teaching materials, smart school, Field Work Practice.

Copyright (c) 2021 Nurjannah, Sugeng Widodo, Helmy Fitriawan

$\triangle$ Corresponding author

Email : Nurjannah3086@gmail.com

DOI : https://doi.org/10.31004/edukatif.v3i4.537

ISSN 2656-8063 (Media Cetak)

ISSN 2656-8071 (Media Online)

Edukatif : Jurnal Ilmu Pendidikan Vol 3 No 4 Tahun 2021 p-ISSN 2656-8063 e-ISSN 2656-8071 
1211 Pengembangan Bahan Ajar Matematika Berbasis Smart School pada Kegiatan Praktek Kerja Lapangan di SMK - Nurjannah, Sugeng Widodo, Helmy Fitriawan

DOI: https://doi.org/10.31004/edukatif.v3i4.537

\section{PENDAHULUAN}

Praktek Kerja Lapangan (PKL) sebagai ciri khas dari Sekolah Menengah Kejuruan (SMK) merupakan bentuk penyelenggaraan pendidikan keahlian yang memadukan secara sistematik dan sinkron antara program pendidikan di sekolah dengan program penguasaan kompetensi yang diperoleh melalui suatu tingkat kompetensi tertentu (Zyainuri \& Marpanaji, 2013). Penyelenggaraan PKL, agar sesuai harapan penyelenggaraan pendidikan kejuruan, maka dalam implementasinya harus "diadministrasikan" atau dikelola dengan baik. Pengelolaan adalah sebuah proses perencanaan, pengorganisasian, pengordinasian dan pengontrol sumber daya untuk mencapai sasaran secara efektif da efisien, (Ridhotullah S, 2015). Sesuai dengan (Depdiknas, 2017) tentang: Standar Pengelolaan Pendidikan oleh Satuan Pendidikan Dasar dan Menengah meliputi: (1) Perencanaan Program, (2) Pelaksanaan Rencana Kerja, (3) Pengawasan atau Evaluasi. PKL adalah suatu cara menyelenggarakan pendidikan dan pelatihan kejuruan khususnya pada Sekolah Menengah Kejuruan (SMK) yang memadukan kegiatan belajar di sekolah dan kegiatan belajar melalui bekerja secara langsung pada bidang serta suasana yang sesungguhnya dan relevan di lapangan kerja/dunia usaha dan atau dunia industri dengan harapan terjadi link and match atau keterkaitan dan kesepadanan antara sekolah dengan dunia industri.

Pendidikan jarak jauh merupakan konsep pembelajaran mandiri, seperti yang digambarkan Moore dan kearsley (Parwitaningsih \& Darmayanti, 2010) bahwa belajar jarak jauh memepunyai karakteristik unik, yaitu adanya keterpisahan secara fisik antara pengajar dan peserta didik, karakteristik tersebut adalah yang membedakan belajar jauh dengan pendidikan tatap muka. Sedangkan belajar dalam jaringan (daring) merupakan salah satu proses belajar yang menuntut peserta didik untuk masuk kelas dalam jaringan Internet dengan sarana utama pengiriman materi pembelajaran dan interaksi kelasnya dilaksanakan melalui hubungan dengan internet.

Kehadiran teknologi informasi dan komunikasi dalam kehidupan telah mengubah paradigma pendidikan yang menerapkan guru sebagai fasilitator dan agen pembelajaran dimana peseserta didik dapat memiliki akses yang seluas-luasnya kepada beragam media untuk kepentingan pendidikan. Salah satu alternatif yang membuat pelajaran matematika menjadi lebih menarik dan siswa dapat berperan aktif adalah diciptakan suatu bahan ajar maupun media pembelajaran. Guru sebagai pengajar menjadi fokus dalam kegiatan belajar mengajar karena perannya yang sangat menentukan guru harus mampu mentransformasikan pengetahuan yang dimilikinya kepada siswa.

Bahan ajar merupakan segala bahan (baik informasi, alat maupun teks) yang disusun secara sistematis yang menampilkan sosok utuh dari kompetensi yang akan dikuasai peserta didik dan digunakan dalam proses pembelajaran dengan tujuan untuk perencanaan dan penelaahan implementasi pembelajaran (Prastowo, 2014). Menurut (Masjid, 2012) bahan ajar yang digunakan dalam pembelajaran dapat diklasifikasikan menjadi: Bahan ajar cetak yang terdiri dari handout, buku pelajaran, modul, foto/gambar. Bahan ajar dengar yaitu kaset atau piringan hitam atau compact disk dan radio. Bahan ajar pandang dengar (audio visual) terdiri dari video atau film, orang atau nara sumber. Bahan ajar multimedia interaktif antara lain seperti CAI, compact disk pembelajaran interaktif dan bahan ajar berbasis web.

Menurut (Prastowo, 2014) bahan ajar modul adalah seperangkat bahan ajar yang disajikan secara sistematis, sehingga penggunanya dapat belajar dengan atau tanpa fasilitator atau guru. Berkembangnya teknologi saat ini sangat membantu dalam dunia pendidikan. Pengembangan dengan memanfaatkan teknologi salah satunya dengan pengembangan bahan ajar berbasis elektronik atau dikenal dengan E-modul.penggunaan E-modul sangat membantu siswa dalam proses kegiatan pembelajaran jarak jauh.

Problematika saat ini adalah masih banyak peserta didik yang mengganggap matematika adalah pelajaran yang sulit. Menurut pendapat (Auliya, 2016) matematika dianggap pelajaran yang sulit karena karakteristik matematika yang bersifat abstrak, logis, sistematis, dan penuh dengan lambang serta rumus yang 
1212 Pengembangan Bahan Ajar Matematika Berbasis Smart School pada Kegiatan Praktek Kerja Lapangan di SMK - Nurjannah, Sugeng Widodo, Helmy Fitriawan

DOI: https://doi.org/10.31004/edukatif.v3i4.537

membingungkan. Dengan kesulitan yang ada menuntut guru untuk berkreativitas mengembangkan bahan ajar yang akan digunakan dalam pembelajaran.

Pada tahun 2019 Pemerintah Provinsi Lampung mengembangkan inovasi pembelajaran berbasis teknologi yang dapat digunakan dalam proses belajar-mengajar dikelas. Inovasi Pembelajaran ini dikhususkan untuk Provinsi Lampung yang dinamakan Aplikasi Smart school Lampung Berjaya. Aplikasi ini merupakan konsep sekolah berbasis teknologi yang memuat fitur pembelajaran seperti bank soal, laboratorium maya, dan kelas digital. Secara pedagogis arah pendidikan terkait dengan pengembangan pendekatan dan metodologi proses pendidikan dan pembelajaran yang memanfaatkan berbagai sumber belajar (multi learning resources).

Bahan ajar yang peneliti kembangkan adalah bahan ajar yang dikemas dalam aplikasi smart school. Bahan ajar ini menghasilkan bahan ajar elektronik yang berisi materi pembelajaran, contoh soal dan tugas. Pada akhir kegiatan pembelajaran terdapat tes formatif yang digunakan untuk mengukur pencapaian komepetensi siswa. Bahan ajar ini juga diharapkan dapat membantu siswa dalam pembelajaran secara mandiri dan memudahkan guru untuk menyampaikan materi pada saat kegiatan Praktek Kerja Lapangan.

Melalui observasi dan wawancara peneliti dan guru di SMK Negeri 4 Bandar Lampung, diketahui bahwa pada saat kegiatan siswa Praktek Kerja Lapangan (PKL) bahwa modul yang diberikan kepada siswa belum efektif, sifatnya masih standar, belum bervariasi dan masih dalam bentuk yang kurang menarik, hal ini dikarenakan modul yang diberikan digabungkan dengan beberapa mata pelajaran lainnya. Bahan ajar cetak yang ada di pasaran pun tidak dapat digunakan di karenakan tidak sesuai dengan silabus. Hal tersebut dapat menghambat proses pembelajaran pada kegiatan PKL.

Dengan adanya bahan ajar berbasis Smart school diharapkan dapat meningkatkan minat siswa dalam pembelajaran matematika. Berdasarkan uraian diatas maka peneliti melakukan penelitian tentang bagaimana keefektifitasan bahan ajar matematika berbasis smart school pada kegiatan Praktek Kerja Lapangan siswa SMK.

Hasil Penenlitian lain yang yang merujuk pada pengembangan bahan ajar salah satunya adalah penelitian oleh Lisa Tania, yang berjudul Pengembangan bahan ajar E-modul sebagai pendukung pembelajaran kurikulum 2013 materi ayat jurnal penyesuaian perusahaan jasa siswa kelas X akutansi SMK Negeri Surabaya (studi kasus pada siswa kelas X Akutansi SMK Negeri 1 Surabaya).

Pada tahun 2019 terdapat penenlitian oleh Indri Lestari dengan judul Pengembangan Bahan Ajar Matematika dengan memanfaatkan program Geogebra untuk Meningkatkan Kemandirian Belajar dengan tingkat kelayakan 78,8\% dari uji ahki media, ahli matematika dan ahli pendidikan. Kemandirian belajar siswa sebelum dan sesudah uji coba produk terdapat peningkatan, meskipun tidak terlalu besar. Pada uji sekala terbatas peningkatan persentase kemandirian belajar siswa sebelum dan sesudah menggunakan bahan ajar sebesar $34 \%$, sedangkan pada uji lapangan peningkatan persentase kemandirian belajar sebelum dan sesudah menggunakan bahan ajar sebesar 8,11\%. dengan melihat beberapa hasil dari penenlitian tersebut, maka perlu adanya pengemabangan teknologi pada media atau aplikasi-aplikasi lain pada materi-mater lain dalam mata pelajaran matematika salah satunya adalah materi statistika.

Berdasarkan latar belakang diatas, maka penulis akan melakukan penelitian pengembangan berjudul Pengembagan bahan ajar Matematika berbasis smart school untuk meningkatkan efektivitas pembelajaran pada kegiatan Praktek Kerja Lapangan siswa SMK.

Berdasarkan latar belakang diatas, dapat dirumuskan permasalahan sebagai berikut : 1) Bagaimanakah pengembangan bahan ajar matematika berbasis Smart school bagi siswa Praktek Kerja Lapangan, 2) Bagaimanakah efektivitas penggunaan bahan ajar matematika berbasis Smart school bagi siswa Praktek Kerja Lapangan, 3) Bagaimanakah respon siswa terhadap kemenarikkan bahan ajar matematika berbasis smart school bagi siswa Praktek Kerja Lapangan.

Berdasarkan rumusan masalah, maka tujuan yang akan dicapai dalam penelitian ini adalah: 1) Melakukan pengembangan produk bahan ajar Matematika berbasis Smart school materi Statistika pada 
1213 Pengembangan Bahan Ajar Matematika Berbasis Smart School pada Kegiatan Praktek Kerja Lapangan di SMK - Nurjannah, Sugeng Widodo, Helmy Fitriawan

DOI: https://doi.org/10.31004/edukatif.v3i4.537

kegiatan siswa Praktek Kerja Lapangan di SMK Negeri 4 Bandar Lampung, 2) menganalisis efektivitas bahan ajar Matematika berbasis Smart school materi Statistika pada kegiatan siswa Praktek Kerja Lapangan di SMK Negeri 4 Bandar Lampung, 3) Menganalisis kemenarikan bahan ajar Matematika berbasis Smart school materi Statistika pada kegiatan siswa Praktek Kerja Lapangan di SMK Negeri 4 Bandar Lampung.

Spesisfikasi produk yang diharapkan pada penelitian pengembangan ini adalah: 1) bahan ajar matematika ini berbasis aplikasi smart school, 2) Bahan ajar matematika ini dapat menjadi bahan ajar yang digunakan pada saat kegiatan siswa Praktek Kerja Lapangan yang sesuai dengan kurikulum 2013 yang mampu mendukung siswa belajar secara mandiri, 3) Bahan ajar matematika berbasis aplikasi smart school mudah untuk mendownloadnya 4) Bahan ajar matematika berbasis smart school ini dilengkapi dengan tugas dan tes formatif untuk mengukur kemampuan siswa dalam belajar.

\section{METODE}

Jenis penelitian ini adalah penelitian pengembangan (research \& development). Menurut (Sugiono, 2017) metode penelitian dan pengembangan (research \& development) merupakan metode penelitian yang digunakan untuk menghasilkan produk baru dan selanjutnya menguji keefektifan produk tersebut. Penelitian ini menggunakan model ADDIE. Model pengembangan ini memiliki lima tahap yaitu : (1) Analyze (analisis), (2) design (perencanaan), (3) development (pengembangan), (4) implementation (implementasi), (5) evaluation (evaluasi). Uji coba dalam pengembangan produk dilakukan dalam tiga tahap yaitu uji satu-satu, uji terbatas dan uji teman sejawat. Uji coba yang peneliti lakukan bertujuan untuk mengetahui kelayakan bahan ajar berbasis smart school yang telah dibuat. Sebelumnya peneliti melakukan validasi terhadap produk yang telah dikembangkan. Setelah melakukan validasi peneliti melakukan analisis revisi bahan ajar berbasis smart school.Subjek uji coba dalam penelitian pengembangan ini adalah: 1) Ahli materi selaku orang yang berkompetensi dalam bidang matematika terdiri dari satu orang guru matematika 2) Ahli media selaku orang yang berkompetensi dalam bidang teknologi yaitu satu orang dosen ilmu komputer 3) Ahli desain pembelajaran selaku orang yang berkompetensi dalam bidang desain pembelajaran yaitu seorang guru matematika 4) siswa kelas XII TKJ 1 di SMK Negeri 4 Bandar Lampung sebanyak 26 siswa.

Data hasil penelitian ini terbagi menjadi dua yaitu tes dan nontes. Instrumen-instrumen ini diberikan sesuai dengan subjek pada penelitian pengembangan. 1) Instrumen studi pendahuluan. Instrumen yang digunakan oleh peneliti adalah lembar wawancara. Lembar wawancara digunakan untuk melakukan wawancara dengan peserta didik mengenai bahan ajar yang digunakan pada saat kegiatan praktek kerja lapangan, 2) Instrumen validasi bahan ajar berbasis smart school. Instrumen dalam validasi bahan ajar berbasis smart school diserahkan kepada ahli materi, ahli media dan ahli desain. Instrumen yang diberikan berupa pernyataan dalam skala likert dengan empat pilihan jawaban, yaitu (4) Sangat Baik, (3) Baik, (2) Kurang Baik, (1) Tidak baik, serta dilengkapi dengan komentar dan saran para ahli. 3) Instrumen uji satusatu/uji perorangan. Instrumen ini diberikan kepada peserta didik yang menjadi subjek uji perorangan bahan ajar berbasis smart school. Untuk mengetahui ada atau tidak kesalahan tulisan di bahan ajar tersebut dan bagaimana keterbacaan terhadap produk yang dikembangkan. 4) Instrumen uji terbatas. Terdapat instrumen tes dan nontes yang digunakan dalam penelitian ini. Dalam kegiatan ini, peneliti harus mempersiapkan instrumen pengembangan bahan ajar. Instrumen ini diberikan pada peserta didik di akhir materi. Sebelum diberikan di akhir materi, instrumen ini diuji cobakan terlebih dahulu pada kelas lain untuk mengetahui validitas, relibilitas, tingkat kesukaran dan daya pembeda.

Dalam pengembangan ini digunakan dua teknik analisis data yaitu analisis deskriptif kuantitatif dan analisis deskriptif kualitatif. Analisis deskriptif kuantitatif digunakan untuk melihat efektivitas bahan ajar matematika berbasis smart school materi statistika dalam pembelajaran matematika pada kegiatan siswa PKL. Data analisis adalah data hasil tes kemampuan matematika pada materi statistika yang dilaksanakan pada akhir 
1214 Pengembangan Bahan Ajar Matematika Berbasis Smart School pada Kegiatan Praktek Kerja Lapangan di SMK - Nurjannah, Sugeng Widodo, Helmy Fitriawan

DOI: https://doi.org/10.31004/edukatif.v3i4.537

pembelajaran. Untuk melihat efektivitas bahan ajar berbasis smart school materi statistika, hasil analisis data ini akan dibandingkan dengan Kriteria Ketuntasan Minimal (KKM) pada pelajaran matematika yaitu $\geq 75 \%$ siswa mencapai nilai KKM $(\mathrm{KKM}=75)$. Dan untuk melihat besarnya peningkatan dan kategori efektifitas juga dapat dihitung menggunakan rumus $\mathrm{N}$ -

Gain berikut:

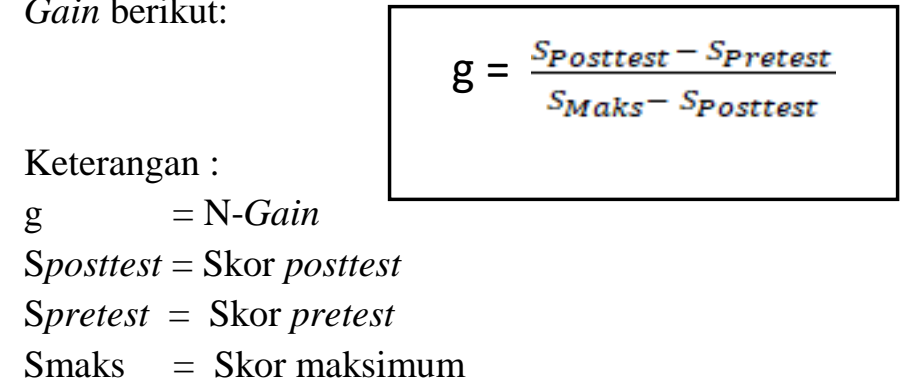

Hasil perhitungan N-Gain diinterpretasikan dengan menggunakan klasifikasi Hake (Meltzer, 2012) Tingkat efektivitas berdasarkan rata-rata nilai N-Gain dapat dilihat pada Tabel 1.

Tabel 1 Nilai Rata-rata N-Gain dan Klasifikasinya

\begin{tabular}{c|c|c}
\hline Rata-rata N-Gain & Klasifikasi & Tingkat efektivitas \\
\hline$(\mathrm{g}) \geq 0,70$ & Tinggi & Efektif \\
$0,30 \leq(\mathrm{g})<0,70$ & Sedang & Cukup Efektif \\
$(\mathrm{g})<0,30$ & Rendah & Kurang Efektif \\
\hline
\end{tabular}

Sedangkan analisis deskriptif kualitatif digunakan untuk mengetahui respon siswa terhadap bahan ajar statistika berbasis smart school yang ditinjau dari kemenarikan kemudahan dan kelayakan.

Tabel 2 Kriteria kemenarikan dan kemudahan (Hermeliyati Pitri, 2016)

\begin{tabular}{c|c|l|l}
\hline NO & $\begin{array}{l}\text { Skor rata-rata } \\
\text { Angket }\end{array}$ & \multicolumn{1}{|c}{ Kriteria Menarik } & \multicolumn{1}{c}{ Kriteria Kemudahan } \\
\hline 1 & $1-1,9$ & Sangat kurang menarik & Sangat sulit dipahami \\
2 & $2-2,9$ & Kurang Menarik & Kurang dipahami \\
3 & $3-3,9$ & Menarik & Mudah dipahami \\
4 & 4 & Sangat Menarik & Sangat Mudah dipahami \\
\hline
\end{tabular}

Dari Tabel 2 terlihat bahwa skor rata-rata angket dari kriteria yang sudah di tentukan akan menghasilkan data deskriptif kualitatif mengenai kemanarikan dan kemudahan bahan ajar statistika berbasis smart school. Kriteria kelayakan yang menyatakan bahwa produk yang dikembangkan layak untuk digunakan disajikan pada Tabel 3 berikut.

Tabel 3 Skala Persentase Kelayakan (Arikunto S, 2016)

\begin{tabular}{cc}
\hline Persentase pencapian & Interprestasi \\
\hline $76-100 \%$ & Sangat Layak \\
$56-75 \%$ & Layak \\
$40-55 \%$ & Cukup \\
$0-39 \%$ & Tidak Layak \\
\hline
\end{tabular}

Tabel 3 menunjukkan bahwa skor rata-rata angket dari kriteria yang sudah di tentukan akan menghasilkan data deskriptif kualitatif mengenai kelayakan produk bahan ajar statistika berbasis smart school.

\section{HASIL DAN PEMBAHASAN}

Hasil pengembangan bahan ajar menggunakan model ADDIE, yang terdiri dari lima tahap yaitu tahap analisis, tahap perencanaan, tahap pengembangan, tahap implememntasi dan tahap evaluasi. Bahan ajar yang 
1215 Pengembangan Bahan Ajar Matematika Berbasis Smart School pada Kegiatan Praktek Kerja Lapangan di SMK - Nurjannah, Sugeng Widodo, Helmy Fitriawan

DOI: https://doi.org/10.31004/edukatif.v3i4.537

dikembangkan berupa modul yang diunggah kedalam aplikasi smart school. Bahan Ajar dalam pembelajaran Matematika khususnya materi Statistika di kembangkan dengan memperhatikan kondisi dan potensi siswa SMK Negeri 4 Bandar Lampung. Kondisi dan Potensi dianalisis melalui studi pendahuluan dengan observasi, wawancara, dan penyebaran angket untuk mengetahui bagaimana pembelajaran dilakukan selama ini pada saat siswa Praktek Kerja Lapangan (PKL), ada atau tidaknya produk yang dikembangkan, tingkat kebutuhan siswa dan guru terhadap perkembangan produk yang dikembangkan.

Observasi dilakukan di SMK Negeri 4 Bandar Lampung menunjukkan bahwa belum ada bahan ajar berbasis Smart school yang digunakan dalam pembelajaran terutama pada saat siswa PKL. Bahan ajar yang digunakan dalam proses pembelajaran adalah modul yang dibuat oleh guru bidang studi yang digabungkan dengan materi-materi dari mata pelajaran lainnya. Hasil wawancara dan angket yang dilakukan terhadap siswa dan guru diketahui bahwa siswa enggan membaca modul yang diberikan, karena materi yang disajikan dalam modul kurang lengkap, tampilan modul yang kurang menarik dan siswa terbiasa memahami materi berdasarkan penjelasan guru. Pada saat PKL siswa hanya memiliki waktu yang terbatas untuk belajar sehingga membutuhkan bahan ajar yang efisien. Berdasarkan hasil observasi dan wawancara tersebut disimpulkan bahwa kondisi pembelajaran belum berjalan dengan baik selama kegiatan PKL. Siswa membutuhkan bahan belajar yang efektif yang dapat dipelajari kapan saja, mudah dipahami dan menarik.

Pada tahap ini memuat tiga cakupan yaitu analisis kebutuhan, analisis materi dan analisis peserta didik. Pada analisis kebutuhan dilakukan kegiatan studi lapangan dan studi literatur untuk menganalisis kebutuhan siswa dan guru. Data diperoleh dari observasi, wawancara, dan angket. Pada tahap ini observasi merupakan kegiatan pendahuluan untuk mendapatkan data awal yang dijadikan dasar pengembangan. Data yang digunakan merupakan gambaran kondisi pembelajaran yang berlangsung (meliputi kesiapan guru dan siswa, media pembelajaran dan sarana prasarana), serta hasil belajar siswa.

Hasil observasi dan wawancara menunjukkan bahwa peserta didik merasa bahwa bahan ajar yang selama ini digunakan dalam kegiatan PKL sulit dipahami dan berupa bahan ajar cetak yang kurang menarik. Sedangkan guru merasa bahan ajar yang selama ini digunakan kurang efektif dan belum berbasis teknologi. Kemudian melakukan analisis karakteristik peserta didik tentang kapasitas belajarnya, pengetahuan, keterampilan, sikap, yang telah dimiliki peserta didik serta aspek lain yang terkait.

Pada analisis materi dilakukan kegiatan menganalisis materi yang akan dipilih dalam penelitian ini sesuai dengan kurikulum yang digunakan di SMK Negeri 4 Bandar Lampung, yaitu kurikulum 2013. Materi yang dipilih disesuaikan dengan waktu penelitian dan program semester yang telah disusun pada awal tahun pembelajaran. Materi yang digunakan pada penelitian ini adalah materi statistika.

Analisis peserta didik dilakukan melalui wawancara dan observasi pada siswa kelas XII SMK negeri 4 Bandar Lampung dalam pembelajaran matematika. Berdasarkan analisis peserta didik, didapatkan beberapa kesimpulan: 1) Pada saat kegitan Praktek Kerja lapangan peserta didik kesulitan dalam memahami materimateri pelajaran yang diberikan, 2) Media pembelajaran pada saat PKL belum berbasis teknologi, 3) Bahan ajar yang diberikan sulit dipahami karena penyajiannya yang sederhana dan kurang lengkap, 4) Bahan Ajar yang selama ini digunakan adalah bahan ajar yang berisi berbagai macam pelajaran dan tidak memungkinkan untuk selalu dibawa, karena ukuran yang besar dan tebal, 5) Hasil angket menunjukkan bahwa guru mata pelajaran matematika membutuhkan bahan ajar yang berbasis teknologi sehingga dapat meningkatkan efektivitas dan hasil belajar siswa pada saat PKL.

Pada tahap perancangan, bahan ajar yang dikembangkan merupakan bahan ajar berupa modul matematika materi statistika yang diunggah kedalam aplikasi smart school. Tahap ini mulai dengan merumuskan tujuan pembelajaran terlebih dahulu. Tujuan pembelajaran khusus berupa indikator dan tujuan pembelajaran secara umum berupa SK dan KD (diuraikan dilampiran) yang disesuaikan dengan kompetensi inti dan kompetensi dasar pada kurikulum 2013. Bahan ajar ini terdiri dari 3 sub bab yang memuat materi pengumpulan data, penyajian data, Ukuran pemusatan data (mean, median, modus) tunggal dan berkelompok. 
1216 Pengembangan Bahan Ajar Matematika Berbasis Smart School pada Kegiatan Praktek Kerja Lapangan di SMK - Nurjannah, Sugeng Widodo, Helmy Fitriawan

DOI: https://doi.org/10.31004/edukatif.v3i4.537

Tahap pengembangan bahan ajar dilakukan sesuai dengan rancangan. Terdapat beberapa kegiatan pada tahap pengembangan ini, yaitu uji validasi ahli, revisi bahan ajar berdasarkan hasil uji validasi, uji coba lapangan awal dan revisi bahan ajar berdasarkan hasil uji coba lapangan awal. Bahan ajar matematika yang telah disusun diunggah kedalam aplikasi smart school. Pengguna yaitu siswa diberikan link kelasmaya.belajar.kemendikbud.go.id. untuk masuk kedalam aplikasi smart school. Siswa login menggunakan akun yang dimiliki kemudian pendidik memberikan kode kelas yang akan diikuti. Selanjutnya siswa mengikuti kegiatan pembelajaran dalam aplikasi smart school. Pada saat siswa mengklik modul pada aplikasi smart school otomatis bahan ajar terdownload. Selanjutnya pada tahap ini uji telaah dan uji validasi. Uji telaah dan uji validasi bertujuan untuk mendapatkan komentar, saran, dan penilaian terhadap perbaikan bahan ajar. Uji telaah dan uji validasi oleh ahli materi, ahli media dan ahli desain pembelajaran dilakukan kepada dosen dan guru yang berkompeten dalam bidangnya. Data telaah bahan ajar adalah data kulitatif yang berisi saran dan komentar terhadap perbaikan bahan ajar. Uji validasi akan menghasilkan data kuantitatif berupa penilaian dalam skala angka yang terhadap produk bahan ajar. Pada Gambar 1 adalah gambar aplikasi smart school.

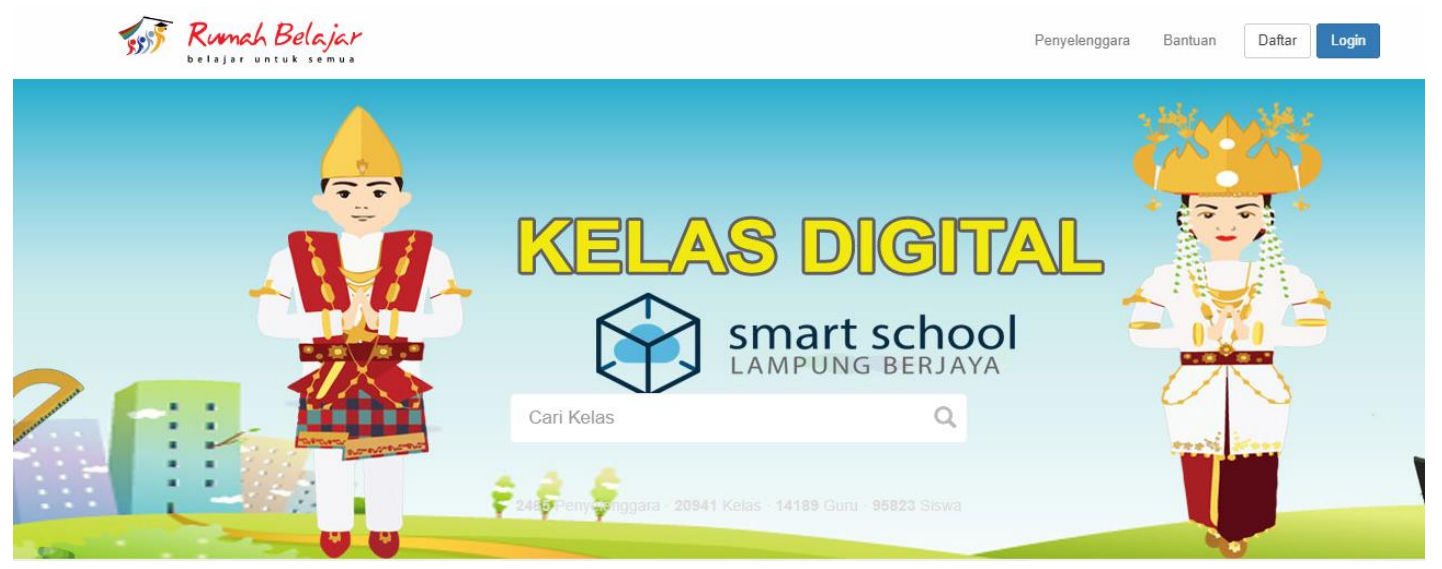

Gambar 1 Apliakasi Smart school

Berdasarkan pengolahan data hasil validasi oleh para ahli, diperoleh hasil penilaian untuk : Ahli media pembelajaran. Lembar penilaian ahli media terdiri 21 kriteria penilaian, dengan frekuensi jawaban total ahli media sebesar 81 dan jumlah skor ideal adalah 84. Persentase rata-rata yang didapat dari penilaian ahli media adalah 96,43 \% dalam skala persentase kelayakan menghasilkan kriteria sangat baik, dengan kategori penilaian sangat layak maka dari skor tersebut bahan ajar dapat digunakan dilapangan. Lembar penilaian ahli media terdiri 17 kriteria penilaian dengan total frekuensi jawaban ahli materi sebesar 63 dan jumlah skor ideal adalah 68. Nilai persentase rata-rata didapat $92,65 \%$ dalam skala persentase kelayakan menghasilkan kriteria sangat baik dengan kategori penilaian sangat layak, maka dari skor tersebut bahan ajar dapat digunakan.Lembar penilaian ahli desain terdiri 14 kriteria penilaian dengan total frekuensi jawaban ahli desain sebesar 53 dan jumlah skor ideal adalah 56. Nilai perentase rata-rata yaitu 89,28\% dalam skala persentase kelayakan menghasilkan kriteria sangat baik dengan kategori penilaian sangat layak, maka dari skor tersebut bahan ajar dapat digunakan dilapangan. Uji satu-satu/perseorangan (3 responden) Bahan ajar yang telah direvisi berdasarkan ahli media, ahli materi dan ahli desain pembelajaran selanjutnya diuji cobakan kepda peserta didik. Uji coba ini adalah uji coba tahap awal yang di ujikan kepada 3 orang peserta didik. Uji coba ini di maksudkan untuk mengenalkan produk bahan ajar yang dikembangkan kepada pengguna (responden) dengan tujuan untuk melihat keterpakaian produk (user friendly) pada pengguna sebenarnya. Bahan ajar yang telah direvisi, diuji cobakan pada tiga orang peserta didik kelas XII TKJ 1 yang akan menempuh materi statistika dengan kemampuan tinggi, sedang dan rendah. Uji perorangan difokuskan dalam penggunaan bahan 
1217 Pengembangan Bahan Ajar Matematika Berbasis Smart School pada Kegiatan Praktek Kerja Lapangan di SMK - Nurjannah, Sugeng Widodo, Helmy Fitriawan

DOI: https://doi.org/10.31004/edukatif.v3i4.537

ajar melalui aplikasi smart school. Pada akhir kegiatan, siswa diberikan pertanyaan dalam bentuk angket mengenai penggunaan bahan ajar berbasis smart school.

Penilaian 3 orang responden terhadap 15 pertanyaan didapat jumlah frekuensi jawaban responden sebesar 137, maka dihasilkan rata-rata 3,04 atau 76, $11 \%$ dengan kriteria menarik dan mudah dipahami. Dapat disimpulkan bahwa bahan ajar berbasis smart school yang dikembangkan mendapat respon yang baik dari peserta didik. Akan tetapi, peserta didik masih memberikan saran perbaikan yaitu beberapa kesalahan pengetikan, gambar-gambar yang masih kurang jelas dan pembahasan tes formatif yang belum dijabarkan pada bahan ajar. Selanjutnya dilakukan revisi berdasarkan masukan peserta didik.

Uji Terbatas (26 reponden siswa dan 5 responden guru). Bahan ajar yang telah di uji cobakan kepada 3 responden dan dilakukan revisi (revisi II) di uji cobakan kembali. Uji coba pada tahap ini adalah uji terbatas dengan 26 responden siswa dan 5 orang responden guru matematika. Kategori penilaian terhadap 26 responden dengan 15 pertanyaan, didapat frekuensi jawaban responden sebesar 1264, dihasilkan rata-rata 3,24 atau $76,61 \%$ dalam skala empat dengan kriteria menarik dan mudah dipahami. Dapat disimpulkan bahwa bahan ajar berbasis smart school yang dikembangkan mendapat respon yang baik dari peserta didik. Akan tetapi, peserta didik masih memberikan saran perbaikan yaitu masih ada beberapa kesalahan pengetikan, dan gambar yang masih kurang jelas. Selanjutnya dilakukan revisi kembali berdasarkan masukan peserta didik. Penilaian dari 5 orang responden teman sejawat terhadap 4 aspek yang dinilai, yang terdiri dari 18 pertanyaan dengan frekuensi jawaban responden sebesar 334 mengasilkan rata-rata 3, 71 atau 92,78\% dalam skala empat dengan kriteria sangat baik, menarik dan mudah dipahami.

Pada tahap implementasi, bahan ajar digunakan dalam pembelajaran pada saat siswa Praktek Kerja Lapangan untuk meihat keefektivitasannya. Bahan ajar ini digunakan dalam pembelajaran matematika kelas XII jurusan Teknik Komputer dan Jaringan (TKJ) 1 SMK Negeri 4 Bandar Lampung pada semester ganjil tahun ajaran 2020/2021 dengan jumlah peserta didik 26 orang.

Tahap evaluasi adalah tahap akhir dari penelitian pengembangan ini. Selama Praktek Kerja lapangan (PKL) siswa menggunakan bahan ajar matematika berbasis smart school. Hasil ulangan materi statistika pada siswa kelas XII TKJ 1 yang berjumlah 26 orang menunjukkan ada 5 orang yang belum mencapai SKM yaitu sebesar 19,23\%, sedangkan siswa yang telah mencapai SKM sebesar 80,77\%. Hasil ulangan statistika dapat dilihat pada Tabel 4 berikut :

Tabel 4 Persentase Hasil Postest

\begin{tabular}{l|r}
\hline \multicolumn{2}{c}{ Persentase Postest } \\
Siswa dengan nilai $\geq 75$ & $80,77 \%$ \\
Siswa dengan nilai $\leq 75$ & $19,23 \%$ \\
\hline
\end{tabular}

Dari tabel rekapitulasi postes (Pada lampiran) didapat rata-rata hasil belajar siswa sebesar 77,7 artinya hasil belajar siswa telah memenuhi Standar Ketuntasan Minumum (SKM) secara klasikal yang ditetapkan oleh sekolah dengan nilai SKM sebesar 75. Hal ini berarti bahwa bahan ajar statistika berbasis smart school cukup baik untuk dipakai dalam pembelajaran matematika pada kegiatan siswa Praktek Kerja Lapangan (PKL). Sedangkan siswa yang belum mencapai SKM sebesar 19,23\%, hal ini dipengaruhi oleh beberapa faktor diantaranya siswa-siswa tersebut kurang paham dalam penggunaan teknologi dan kurang pandai membagi waktu belajar dan praktik.

Berdasarkan hasil rekapitulasi angket kemenarikan dan kemudahan terhadap 3 orang siswa pada uji perorangan diperoleh rata-rata 3,04 dan pada uji terbatas pada 26 siswa diperoleh rata-rata 3,17. Jika ditafsirkan pada tabel konversi bahwa kemenarikan dan kemudahaan bahan ajar matematika berbasis smart school materi statistika tergolong menarik dan mudah dipahami. Respon siswa yang positif berdasarkan 
1218 Pengembangan Bahan Ajar Matematika Berbasis Smart School pada Kegiatan Praktek Kerja Lapangan di SMK - Nurjannah, Sugeng Widodo, Helmy Fitriawan

DOI: https://doi.org/10.31004/edukatif.v3i4.537

angket kemenarikan dan kemudahan ini dipengauhi beberapa faktor diantaranya: penyajian bahan ajar yang menarik, platform smart school merupakan sesuatu yang baru dan membuat siswa termotivasi untuk belajar, contoh-contoh soal yang membuat siswa dapat belajar mandiri, tes formatif dengan jawaban soal yang membantu siswa memahami soal-soal, modul yang dapat dipelajari dimana saja, kapan saja, serta penggunaan bahasa pada modul mudah dipahami. Tampilan bahan ajar dengan kombinasi warna yang menarik mampu mempengaruhi perilaku dan sikap siswa saat belajar. Hal ini sejalan dengan pendapat (Sudjana Nana, 2012) yang menyebutkan bahwa media yang mengkombinasi antara visual dan warna dengan maksud untuk menagkap perhatian siswa akan menanamkan gagasan berarti dalam ingatannya. Bahan ajar matematika berbasis smart school ini dapat dipelajari siswa kapan saja, dimana saja, dapat dibaca melalui handphone, komputer ataupun note book. Aktivitas belajar dapat dilakukan dengan mudah dan memotivasi siswa jika berbasis teknologi. Hasil penenlitian (Hendrastomo, 2018) bahwa ketersediaan akses internet sangat diperlukan dalam pembelajaran berbasis teknologi seperti E-learning karena pembelajaran ini selalu menggunakan dan memamfaatkan jaringan internet.

Menurut (Rohmawati, 2015; 17) efektivitas adalah ukuran keberhasilan dari suatu proses antar siswa maupun anatar siswa dengan guru dalam situasi edukatif untuk mencapai tujuan pembelajaran. Efektivitas pembelajaran dapat dilihat dari aktivitas siswa selama pembelajaran berlangsung, respon siswa terhadap pembelajaran dan penugasan konsep siswa.

Bahan ajar matematika berbasis smart school dirancang untuk menigkatkan efektivitas pembelajaran siswa kelas XII SMK Negeri 4 Bandar Lampung pada kegiatan PKL agar siswa dapat belajar secara mandiri. Penggunaan bahan belajar matematika berbasis smart school dalam pengembangan materi statistika merupakan salah satu upaya agar pesan pembelajaran dapat sampai kesiswa. Hasil rata-rata postes adalah 77,7 dan siswa yang mencapai SKM sebesar 80, $77 \%$. Bahan ajar ini dinilai efektif dalam meningkatkan aktivitas siswa dalam belajar mandiri. Berdasarkan perhitungan nilai rata-rata $\mathrm{N}$-gain pada peserta didik yang menggunakan bahan ajar berbasis smart school adalah 0,54 dengan klasifikasi sedang dan tingkat efektivitas cukup efektiv. Hal ini berarti bahan ajar matematika berbasis smart school materi statistika cukup efektif dalam meningkatkan efektivitas pembelajaran pada kegiatan Praktek Kerja Lapangan siswa SMK.

\section{KESIMPULAN}

Bahan ajar matematika berbasis smart school ini dibuat melalui tahap penelitian dan pengembangan dengan hasil siswa yang telah mencapai Standar Kelulusan Minimal (SKM) lebih dari 75\% yaitu 80,77\% dan hasil analisis menggunakan $\mathrm{N}-$ Gain menghasilkan nilai rata-rata 0,54 dengan klasifikasi sedang, dengan persentase 54\% tergolong kedalam kategori cukup efektif dalam meningkatkan efektivitas pembelajaran matematika pada kegiatan siswa Praktek Kerja Lapangan.

\section{DAFTAR PUSTAKA}

Arikunto S. (2016). Metode Penelitian Kuantitatif. Jakarta: Bumi Aksara.

Auliya, R.N. (2016). Kecemasan Matematika dan Pemahaman Matematis. Formatif: Jurnal Ilmiah Pendidikan MIPA

Depdiknas. (2017). Standar Pengelolaan Pendidikan Oleh Satuan Pendidikan Dasar dan Menengah (Jakarta). Jakarta : Depdiknas.

Hendrastomo, G. (2018). dilema dan Tantangan Pembelajaran E-Learning (The Dilemma and the Challenge of Majalah Ilmiah Pembelajaran

Hermeliyati Pitri. (2016). Pengembangan lembar Kerja Siswa Pada Materi Program Linier Dengan Model 
1219 Pengembangan Bahan Ajar Matematika Berbasis Smart School pada Kegiatan Praktek Kerja Lapangan di SMK - Nurjannah, Sugeng Widodo, Helmy Fitriawan

DOI: https://doi.org/10.31004/edukatif.v3i4.537

Pembelajaran Berbasis Masalah. (Tesis). Universitas Bandar lampung. lampung $58 \mathrm{Hlm}$.

Lestari, Indri (2019). Pengembangan Bahan Ajar Matematika dengan Memanfaatkan Program Geogebra Untuk Meningkatkan Kemandirian Belajar. Jurnal Kajian Pendidikan Indonesia. Volume 5 Nomor 1. 2019.

Masjid, A. (2012). Perencanaan Pembelajaran. PT Remaja Rosdakarya. Bandung.

Meltzer, D. E. (2012). The relationship between mathematics preparation and conceptual learning gains in physics: A possible "hidden variable" in diagnostic pretest scores. American Journal of Physics, J Phy.70.1260.

Parwitaningsih, \& Darmayanti, T. (2010). Modal Sosial dan Modal Manusia pada Pendidikan Jarak Jauh di Universitas Terbuka. Jurnal Pendidikan Terbuka Dan Jarak Jauh, Volume.2 Nomor.1. 2010.

Prastowo, A. (2014). Pengembangan Bahan Ajar Tematik. Jakarta: Kencana Prenadamedia Group.

Ridhotullah S. (2015). Pengantar Manajemen. Cetakan pertama. Prestasi Putakarya. Jakarta.

Rohmawati, A. (2015). Efektivitas Pembelajaran. Jurnal Pendidikan Usia Dini, Volume Nomor 1. 2015.

Sudjana Nana. (2012). Penilaian Hasil proses Belajar Mengajar. Bandung: Remaja Rosdakarya.

Sugiono. (2017). Metode Penelitian Kuantitatif Kualitatif dan $r \& d$. Bandung: Alfabeta.

Zyainuri, Z., \& Marpanaji, E. (2013). Penerapan e-learning moodle untuk pembelajran siswa yang melaksanakan prakerin. Jurnal Pendidikan Vokasi, Volume .2 Nomor 3. 2012. 